\title{
Sustainability and stakeholder approach in Olivetti from 1943 to 1960: a lesson from the past $^{1}$
}

\author{
Mauro Sciarelli - Mario Tani
}

\begin{abstract}
Purpose of the paper: The sustainable enterprise focuses on its stakeholders' interests. Today this perspective is a central one in the dialogue on enterprise goals and on the nature of the firm but it was already clear in the past history of some enlightened entrepreneurs like Adriano Olivetti. This important entrepreneur was able to balance economic responsibility and social ones in his managerial model and he showed that the pillars of sustainability, as we call them today, were internally coherent.

Methodology: We apply an interpretative framework (Carroll's pyramid) to analyze the entrepreneurial choices by Adriano Olivetti according to the various perspectives of Corporate Social Responsibility. Our analysis is based upon Adriano Olivetti's texts and the transcriptions of his speeches, his biographies, and on interviews to managers that were active during the years of Adriano Olivettis administration of the Olivetti Group or later experienced the values left in the company after his untimely death.

Findings: This article highlights how their extraordinary experience has demonstrated the full compatibility between social and economic responsibilities. Moreover, the article proves that the various dimensions of corporate social responsibility are tightly connected. Finally, it shows how good stakeholder management practices are a successful strategy.

Research Limits: The article's main limitation is that it is mostly based on anecdotal evidence and secondary sources.

Practical implications: The analytical framework we employ can be useful in driving responsible management processes for modern managers and entrepreneurs.

Originality of the paper: This article proposes two modified versions of a classic model on corporate social responsibility.

Key words: stakeholder management; corporate social responsibility; Olivetti; community; relationships
\end{abstract}

\section{Introduction}

The idea of managing firms' value creation process, engaging all stakeholders, has become widespread in strategic management literature (Freeman, 1984; Ackermann and Eden, 2011; Verbeke and Tung, 2013).

This attention to focus on the economic and social dimensions of

1 Even if this article can be considered as the result of a shared effort, the paragraphs can be attributed to the authors as follows: $n$. 1, 3 and 5 were shared between the authors, n. 2 and 4.1 to Mauro Sciarelli, n. 4, 4.2, 4.3 and 4.4 to Mario Tani,. 
Sinergie Vol. 33, N. 96, 2015

performance has become stronger due to the current economic and financial crisis. Recent events have shown the limits of current managerial principles, which are mostly directed towards profit maximization (Ghoshal, 2005). According to some authors today firms need to close the gap between economic and social value creation (Sciarelli, 1999; Sen, 1987).

In the past decades several scholars have carried out various studies on the relationship between these two topics without finding a clear answer to the question of the real impact of social performance on the financial one. Some have found that increasing expenses on activities linked to corporate social performance does reduce financial performance (Wright and Ferris, 1997), while others have found a positive relationship between them (Orlitsky et al., 2003). Finally, some authors have found that there is no significant relationship between these two aspects (Patten, 1992; McWilliams and Siegel, 2000). Wood (2010) sustains that the lack of a clear relationship depends on an incorrect perception of what performance really is. Wood (2010) reckons that financial performance is just one of the various ways a company can "perform" in society by taking into account the complex web of relationships that tie the social structure together. Wood (2010) also states that the prominence of the financial dimension is due to the shareholder value myth (Stout, 2012) - i. e. the concept that shareholders are seen as the first, and often the only, actors managers should answer to. Shareholder prominence is just the consequence of a separation fallacy (Freeman et al., 2010) - the false idea that business decisions have no ethical content or implicit ethical point of view. By using a stakeholder perspective, performance has to be redefined in a broader perspective as the value that a company creates for the whole set of stakeholders. According to this theory we can analyze how managers relate with company stakeholders to better understand the roots of its value creation process. The Stakeholder Management perspective can help us figure out the various interactions between the different dimensions of Corporate Social Performance (Carroll, 1979).

The purpose of this article is to show that a similar approach to stakeholders' involvement in firm management has already been used by some enlightened entrepreneurs way before the $80 \mathrm{~s}$. In the years in which Adriano Olivetti was CEO, the Olivetti group clearly shows how the stakeholder approach can affect value creation. At the same time this business case study shows that a strong company-community relationship can create and share value for all involved stakeholders.

Furthermore, this study is coherent with Ghoshal's consideration on bad managerial practices. As management scholars and professors, we have a particular social responsibility towards our stakeholders in developing new, socially oriented, managerial models, as in recent decades "our ideas and theories have done much to strengthen those managerial practices that now we are openly condemning" (Ghoshal, 2005). 


\section{Literature review}

The debate on the real nature of corporate responsibility is still strong in On one hand, there are studies on the stakes that managers have to answer to, on the other there are the different research streams on firm performance. The stockholder theory sees profit maximization as the only responsibility of firms (Friedman, 1962). From this point of view, management's decision making process should take into account only the needs of shareholders (Friedman, 1970; Eisenhardt, 1989). On the contrary, the Stakeholder Theory widens management perspective. According to Clarkson (1995, p. 112) "the economic and social purpose of the corporation is to create and distribute increased wealth and value to all its primary stakeholders' groups, without favoring one group at the expense of others".

This perspective should enable firm management to make decisions while considering all the actors affected by the company's actions and those that can affect them - i. e. the company's stakeholders (Freeman, 1984). At the same time, this theory urges managers to include not only economic results in terms of wealth, but also social ones in terms of value in the value creation process of the firm (Sciarelli, 2012) Stakeholder Management Theory - an approach to strategic management developed by R. E. Freeman (Freeman, 1984) - advances the idea that the firm's success depends on the behavior of the various groups that are interrelated with the company and on their contribution to organization activities (Simon, 1947; Cyert and March, 1963). This theory is linked to resource-dependence theory (Pfeffer and Salancik, 1978) as it sees the firm's survival in the long run as a consequence of the support that it receives from the above-cited actors. Stakeholder management theory is grounded on an ethic of capitalism that is mainly based on freedom, cooperation, and responsibility for undertaken actions. It is rooted in a more complete vision of individuals (Evan and Freeman, 1988) - labeled as stakeholder capitalism - and provides a useful framework to combine the ethical and the economic dimensions within the goals of the firm. This is a managerial theory as it guides managers towards a broader perspective on performance, including all the actors for which the firm should create and share value in its strategic vision (Rusconi, 2007). The firm itself is seen as being embedded in a network of mutually influencing relationships with various stakeholders (Sciarelli and Tani, 2013). Thus, managers have to consider these relationships in their strategies in order to achieve a successful value creation process (Freeman et al., 2010, p. 24). The Stakeholder Management theory approach is descriptive, instrumental, and normative (Donaldson and Preston, 1995). It is descriptive, as it sees the firm as a constellation of interests, both competitive and cooperative. It is instrumental, as it assumes that being strategically responsible to stakeholders can increase economic performance (Jones, 1995). It is normative, as it considers profit as the mere consequence of a conscious behavior aimed at stakeholders' value creation. Managers can enhance this process by engaging stakeholders to increase their collaboration and trust (Clarkson, 1995). What should be noted is that the boundaries of the stakeholder concept are still being debated to date, as different definitions 
sinergie Vol. 33, N. 96, 2015

lead to different perspectives on the theory itself ${ }^{2}$. In this regard it is worth highlighting that - according to our view - using an excessively rigid perspective on stakeholder definition - i. e. limiting it to actors that are influenced by corporate activities or only to relationships based on a legal right - does not represent a proper managerial approach. In fact, using a rigid perspective constrains the theory scope too much and does not help managers correctly consider the entire set of relationships in which the firm is embedded. Furthermore, in the category of "stakeholder" we could also include the actors that influence the other stakeholders of the company without actually having a direct relationship with the firm (Sirgy, 2002; Phillips, 2003). According to Goodpaster (1991) stakeholders management can be divided into two main phases: stakeholder analysis and stakeholder synthesis. In the first phase managers have to identify the firm's stakeholders, the stakes they care for (Freeman, 1984), and the relative network of relationships (Rowley, 1997). The concept of salience is central in this phase; it leads to the use of the stakeholders' legitimacy, power, and the urgency of their stakes to classify them (Mitchell et al., 1997). Stakeholder synthesis, instead, deals with the strategic management of these relationships. Some authors approach it by looking at the potential impact that each stakeholder can exert on the performance (Savage et al., 1991), while others refer to resources interdependence (Frooman, 1999). During the stakeholder synthesis phase managers have to balance economical aspects and ethical values (Goodpaster, 1991), going beyond economic rules to implement ethical principles of behavior (such as justice, transparency, equity) in business activities. The adoption of a systemic view implies that managers should put more effort into integrating the complementary stakeholders' interests, rather than trying only to minimize the risks related to relationships. They should adopt a multi-fiduciary approach to reduce potential and latent conflicts. Rusconi (2007) maintains that Freeman's approach to stakeholder management paves the way for introducing ethical principles and social responsibility in the strategic management domain. Ethics concern the behavior of the individual, his moral principles and his choices and, therefore, enter his decision-making process and behavior towards individual stakeholders. Conversely, social responsibility refers to the configuration of relationships between people and to the sphere of obligations and commitments linking the company to internal and external stakeholders.

Chirieleison (2002) analyzed the genesis and evolution of corporate social responsibility over the last decades, finding a tight link with stakeholder management theory. According to the stream of research on Corporate Social Responsibility, companies are expected to respond to society's needs and to respect the social norms that the actors deem as relevant in their socio-cultural context (Bowen, 1953). When the

2 Hinna (2002) groups the various stakeholder definitions according to the actors' engagement in the value creation process. The categories Hinna identifies are: actors that are affected by the firm's activities; actors that are affected or can affect the firm's activities; actors with a legal right on firm's activities; actors with a close relationship with the firm; and actors that are an active part of the value creation process. (see Hinna, 2002, p. 7). 
company is not able to answer to these external requests it slowly erodes its own power in society as a whole, leading to a lower than expected profitability, and threatening its own survival in the most extreme cases (Davis, 1960).

At the same time, firms' responsibility towards society is not only the consequence of a threat but it represents the result of the process to acknowledge the role that companies have in society. This role is not limited to new wealth creation, but it aims at increasing the community's well-being (Frederick, 1960) while firms operate as a true citizen (McGuire, 1963).

Sethi (1975) defines responsible behavior as the combination of three elements: a social obligation - which emerges out of respect for legal and market norms; a social responsibility - which derives from the company's system of values, traditions and expectations; and social responsiveness - i. e. how the company answers to society's requests and how it anticipates still unfelt social needs. Accordingly Clarkson (1995), building on Carroll (1979), and Wartick and Cochran (1985), classify corporate social responsiveness strategies within a four levels scale: the RDAP scale ${ }^{3}$. This scale ranks managers' approach in relation to stakeholders' requests from those denying the firm's responsibility, i. e. the reactive level, to proactive ones that not only acknowledge its responsibilities but also try to respond to them, going beyond stakeholders' direct requests. Wood (1991) states that there are three main sets of reasons leading companies to a responsible behavior: institutional, organizational, and individual motivations. The firm, as an institution, has to use power in a responsible way or it will likely lose it in the long run (Davis, 1973). The company, as an organization, is responsible for solving the problems that it causes, even indirectly (Preston and Post, 1981). Managers should lead the company while considering the interests of stakeholders and they should take responsibility for the consequences of their choices. According to the Integrative Social Contract Theory (Donaldson and Dunfee, 1994) firms operate in a system of constraints governing how individuals and organizations define their behavior. These constraints are the results of a set of explicit and implicit moral norms that are diffused among all actors in a given society. In 1979, Carroll proposed an interpretative model of CSR. The model distinguishes four stages of increasing responsibility: economic, legal, ethical, and discretionary. The first two are mandatory while the others are voluntary. Management has the responsibility of creating economic value for shareholders by delivering goods and services to the market. Also, managers have to comply with existing laws. Yet, there is ethical responsibility, i. e. conformity with the system of principles, values and social norms of the society. In the end, discretionary responsibilities (e. g. philanthropy) are not based on society's expectations and needs, and are therefore entirely voluntary. A similar model (Sciarelli, 2007) defines the firm's comprehensive social responsibility. This model is built on the premise that economic viability is one of the managers' fundamental responsibilities. In this manner, a firm should be able to give to the community more value than it has taken from it. Its second level refers to the firm's ethical responsibility as the requests that firm's decision making

3 The RDAP scale rates the managerial posture on four levels: Reactive - Defensive - Accomodative - Proactive
Mauro Sciarelli 
sinergie Vol. 33, N. 96, 2015

process aims to create value and to share it between all stakeholders in a balanced way. The third stage concerns the responsibility that each organization has towards the community it operates in. This last level encompasses both environmental and social responsibility and concerning the damages that may be caused by the company and, looking at the bright side, the benefits that a firm's growth can create in terms of economic and social welfare. Finally, there is an optional responsibility, coinciding with discretionary philanthropic interventions that are not directly linked to the main company's activities but extend its actions into social, cultural, and recreational areas.

The strong relationship between the two streams of research has been made clear by Carroll and Bucholtz (2003) who show, in their Corporate Social Performance model, a connection between the pyramid of corporate social responsibility and social issues that are directly linked to stakeholders.

\section{Methodology}

In this study we employ an analytical framework, linking the pyramid of Corporate Social Responsibility defined by Carroll (1979) with the stakeholder management approach proposed by Goodpaster (1991). Our model uses the lens of Corporate Social Responsibility (Carroll, 1979; Clarkson, 1995) to understand how the management of relationships with stakeholders can enhance the company's value creation process, in both the economic and social dimensions.

In particular, the adopted approach is similar to the one chosen by Carroll and Bucholtz (2003) to analyze Corporate Social Performance. We do not focus on the social issues that managers have to face while answering the firms' stakeholders, rather we prefer to adopt a more direct approach following Goodpaster's (1991) vision of stakeholder relationship management. Accordingly, we map the decisions that managers make to answer stakeholders' demands or needs. Only in a later phase do we use this information to understand the firm's strategic stance towards each stakeholder group (Clarkson, 1995), and the relative strategy that management has formulated (Savage et al., 1991). We rely upon a stakeholder-oriented perspective for two main reasons: on the one hand, we hold that this perspective helps us understand the role that managers have assigned to each stakeholder's group in their strategies; on the other hand, we hold that shifting the focus on specific stakeholders groups, in spite of the more general idea of social issues adopted by Carroll and Bucholtz (2000), makes it easier for managers to implement it.

Furthermore, we adopt a modified version of Carroll's pyramid of Corporate Social Responsibility (1979) in the following analysis. Specifically, we do not consider Carroll's level of legal responsibilities, i. e. those responding to the company's need to abide by the law. We took this "step" out as we hold that law-abiding should be considered as a fundamental principle of any good managerial practice. Moreover, the decisions made by all managers to comply with legal norms should not 
be evaluated using an ethical perspective, as they are not voluntary choices.

The above-described analytical framework was applied to the Olivetti Group from 1943 to 1960, the years in which Adriano Olivetti was at the

helm. We focus on this specific case for several reasons. First, the managerial model created by Adriano Olivetti was not only oriented towards profit maximization but it was also designed to increase the value created by the company for the community as a whole. We sustain that Adriano Olivetti's management approach, at least if we focus on some relationships, was really similar to the one that would have been called stakeholder relationship management several decades after his death. Another reason to select the case of the Olivetti Group in the Adriano Olivetti years, is related to the meaningful role that personal ethics had in his approach to management. It was so strong that it was still diffused in the company long after his death.

When Adriano Olivetti managed the Olivetti Group, it was not only able to obtain amazing results in the social dimension but also to achieve impressive economic results. This shows that he was not sacrificing one dimension of performance to attain results in another one. Adriano Olivetti's life has already been the subject of several studies, which have revealed his brilliant and multifaceted personality. Furthermore, Adriano Olivetti was a prolific writer who gave many speeches so we can use his own words to understand his model of an ideal society. Moreover, thanks to the archives of the Adriano Olivetti Foundation we had access to several valuable sources on him. We have had the opportunity to complement these secondary sources with the memory of those who worked at the Olivetti company and breathed its extraordinary cultural model long after Adriano Olivetti's untimely death ${ }^{4}$.

\section{Sustainability and stakeholder approach in Olivetti from 1943 to 1960}

The managerial model designed by Adriano Olivetti was strongly influenced by his own personal ethics and political perspective. He dreamed a firm governance model that was similar to a foundation where stakeholders (shareholders, employees and local community) would have a direct role in managing the company. His death interrupted this project, which would have inevitably found strong resistance in the shareholding structure of the Group itself.

Adriano Olivetti has been labeled as a visionary with a concrete project that was achieved for the most part. He was a man with many interests but, above all, a great entrepreneur (Maggia, 2001). In 1932, when he was just over thirty, he became General Manager and, in 1938, he became chairman and later the CEO of Olivetti when his father Camillo died in 1943 . He remained at the helm of the company until 1960, when he suddenly died from a heart stroke. He left behind a strong company that was widely acknowledged as the world leader in the industry of mechanical technology for office products. In 1958, the Olivetti group employed more than 24,000

4 We would like to thank Beniamino de' Liguori Carino, member of the Adriano Olivetti Foundation Board, and Engr. Bruno Esposito, quality manager at Olivetti since the 1980s. 
sinergie Vol. 33, N. 96, 2015

people all over the world (Ochetto, 2013). When he died, the group had several foreign branches in Europe, South America and the USA (Arrigo, 2003). Adriano Olivetti's "social" vision of the firm is well rooted in his personal history and it shines through his actions and his speeches since the mid-forties when, after coming back to Italy after his forced exile in Switzerland during the Second World War, he returned to lead the Olivetti group in Ivrea. He was really concerned about the firm's goals, social responsibility, and the basis of the relationship between the firm and human beings, and between technology and labour ${ }^{5}$. Adriano Olivetti's managerial vision was to push the company's mission well beyond mere shareholder value creation. According to Gallino (2001), the value creation process was mostly about creating wealth and welfare for the local area and its communities. His understanding of the firm's purpose and social function was rooted in a strong industrial culture. He organized these excellent human resources with a model, derived from Taylor's organizational paradigm, that he studied in the United States. His way to manage the company merged the efficiency principles of the Taylorist model of production with his deep respect of the value of human beings. He integrated these elements by using both organizational models and technical innovations; they were the roots of fruitful relationships between the local context and the company. Adriano Olivetti's attention for innovation made him a man ahead of his times. In the mid-50s he started investing in electronic, computing, data processing, and wordprocessing (Conti, 2006). He invested in the creation of two laboratories in Pisa and in New Canaan (USA) to carry out research in electronics and computing; later he funded another laboratory in Borgolombardo that was focused on computing. The results of these research activities made Olivetti a pioneer in the transistor-based computer market when it started to produce the Class Elea in 1959 way before IBM and other competitors.

Olivetti, under Adriano Olivetti's guidance, can be considered as a stakeholder-oriented and socially responsible company. In Olivetti the relationships between the company and its stakeholders were based on shared ethical values. These relationships were driven by his own values: equity, justice, and respect for the others (i. e., a win-win condition). Adriano Olivetti's social vision of the company was mainly oriented to involve two main groups of stakeholders in the value creation process: employees and the local community. A stakeholder oriented approach to

\footnotetext{
In some speeches he expressed his doubts: "Can a company set its goals? Do they merely lie in a profitability index?" (in Italian: "Può un'industria darsi dei fini? Si trovano questi semplicemente nell'indice dei profitti?" - Olivetti, 2013a, p. 100); "We would like to remember in [the factory] rational rigor, in its organization, in the precise ripetitivity of its cultural and assistential services, the indissoluble unity binding [the factory]... to a technique that we want to serve men, so that they, far from being slaves, will be lead to higher goals" (in Italian: "Abbiamo voluto ricordare nel rigore razionalista [della fabbrica], nella sua organizzazione, nella ripetizione esatta dei suoi servizi culturali e assistenziali, l'indissolubile unità che lega [la fabbrica]... a una tecnica che noi vogliamo al servizio dell'uomo perché questi, lungi dall'esserne schiavo, ne sia accompagnato verso mete più alte" - Olivetti, 2013a, p. 102).
} 
strategic management can be used to analyze relationships with other classes of stakeholders, such as other shareholders, especially the Olivetti family, the unions and the entrepreneurial community in Italy. These stakeholders were Mauro Sciarell Mario Tani Sustainability and stakeholder approach in Olivetti from 1943 to 1960: a lesson from less involved in the firm's management, therefore Adriano Olivetti did not the past deal with them frequently.

\subsection{Employees}

In Adriano Olivetti's vision employees represented the main stakeholders of the company. He believed that a strong relationship with the employees was a necessary step towards the creation of a stable and fruitful network of relationships with other stakeholders. His vision of the relationship between the company and employees was guided by two main principles. He inherited the first one from his father and it led him to see involuntary unemployment as "the most terrible evil that afflicts the working class". The second principle was that progress and technology had to serve people as "the company asks a lot of employees and we have the duty to give back a lot" (Olivetti, 2013a). In order to comply with these two principles he introduced the Taylorist organizational model and the employees increased from 5,500 in 1946 to more than 24,000 in 1958. Olivetti's production was a labor-intensive one and Adriano Olivetti considered human resources as the company's prominent asset (Conti, 2006). For this reason he organized the factory as a way to increase their well-being. The factory as a whole was organized as a comfortable meeting place and the windows were big to give employees the chance to see all the surrounding buildings. These solutions were adopted to avoid employees' alienation, reduce their stress, and improve cooperation. Employees had free access to the library where they could read more than 90,000 volumes, newspapers and journals.

Employee engagement represented an essential part of Adriano Olivetti's vision as he stated in a speech to workers at Ivrea: "a factory may lose its humanity, made of knowledge and understanding. But for this understanding to have real value, it must be mutual and, for this to happen, you have to be able to know where the factory goes and why it goes there. " (Un discorso di Adriano Olivetti, giugno 1945, Archivio Storico Olivetti, Ivrea). It is clear that his perspective on employee engagement was based on the principle of transparent information. In order to attain this condition he published the group's main strategic directions in a newsletter for all employees. The Olivetti hiring process was developed to select the best human resources in Italy and abroad. Adriano Olivetti personally interviewed each graduate potential employee before hiring him ${ }^{6}$ or her in order to evaluate not only his or her competences but also his or her potential. Also, he used to evaluate candidates' cooperation capabilities by means of graphological analysis and by looking at their posture.

Olivetti also cared for schooling its employees by providing both training and career opportunities. The Olivetti group's internal school, Centro Formazione Meccanici, was used to school the kids leaving the

6 Conti (2006) states that in the second half of the 50s, when the group was too big for Adriano Olivetti to personally interview all potential candidates, this activity was carried on with the cooperation of his son Roberto and Engr. Tchou. 
sinergie Vol. 33, N. 96, 2015

primary school. Furthermore, they were taught not only subjects related to their job but also those related to the humanities and arts as a way to increase their education and culture ${ }^{7}$. Accordingly, the best students were encouraged and supported to graduate. In Olivetti's perspective human resources were not only workers but also co-producers of value. In Olivetti, managers usually guided employees through a shared set of values and encouraged them to consider themselves as real team members. They were driven towards excellence and expected to cooperate in order to reach the highest results possible. Managers were asked to reward employees for their cooperation capabilities and give bad marks to people incapable of cooperating.

The cooperation among employees went far beyond the firm's boundaries as demonstrated by the Internal Solidarity Fund. This fund was used to provide additional support in case of illness or accidents and each employee funded it with a small monthly contribution. Blue-collars were directly involved in defining the pace of work. Employees were encouraged to participate in conceiving and designing products (Piol, 2004). In this way Olivetti was able to market some of the best products of that time. All employees had the same opportunities so even blue-collars could be promoted to managerial positions according to their own merits.

In 1948 Adriano Olivetti established the Consiglio di Gestione (Management Council), an independent internal body made up of company and worker representatives. This council had advisory powers regarding work organization, planning manufacturing plants and production, as well as initiatives to improve workers' living conditions also outside of the factory. The Council opinion was binding on allocating resources to social services and influencing business management.

Moreover, Adriano Olivetti established a Center of Psychology in order to increase workers' motivation and reduce stress. He provided better conditions for his workers than his competitors and, consequently, the employees were loyal and committed to Olivetti ${ }^{8}$. Furthermore, he established several social services such as economic, cultural, and moral compensation for the employees' hard work. The Olivetti group had a Carta Assistenziale (Social Welfare Charter) stating "every employee contributes to the company's life [... ] and will therefore be able to access social services and related benefits without considering them a personal concession. Using this perspective we can frame the various initiatives that were introduced in the field of social services for workers. These included: nursery and pediatric services; health care services; a company canteen that employees' families could also attend, and almost free transportation. Another way through which he contributed to his employees' welfare were the housing services that could support employees' families in purchasing and restoring their houses. According to Gallino (2001) Olivetti's social services were living proof of a constant

Ferrarotti (2013) reports a sentence Adriano Olivetti usually said on training and education: "Animals are trained. People are educated".

8 Arrigo (2003) states that Olivetti's employees enjoyed, among other benefits, shorter working hours without pay-cuts, paid Saturdays to work in the fields, and longer maternity leave. 
tension towards quality, combining the search for beauty - an aesthetic Mauro Sciarelli component - and caring for people.

The central role that sales skills had in his vision deserves a special mention. During the 1953 crisis, instead of cutting assembly-line jobs, Sustainability and stakeholder approach in Olivetti from 1943 Adriano Olivetti decided to invest in educating the sales force. Sales force headquarters were moved to Milan and he chose to open Olivetti stores around the world. In 1955 he founded the Centre for Specialized Education of Sales Force in Florence, which is a school where sellers' training was not limited to selling techniques but encompassed studies of various fields of the humanities such as history, the arts, and philosophy, as a way to make them more complete human beings.

\subsection{Community}

For Adriano Olivetti, firms were a prominent actor in a local area's economic and social development. He claimed that managers should take an active role in the local area's life helping the the community to get the better out of the firm's growth (Olivetti, 2014).

The company's duty was to be rooted in a given community as an institution (Gallino, 2001). He built a company-town in Ivrea focusing on urbanism and architectural culture and he used the firm as a driving force for the local area's social development. In 1954, Olivetti founded the Institute for Urban and Local Renewal, a non-profit organization created to promote depressed areas like the Canavese one by fostering entrepreneurship (i. e., opening new factories and creating new and innovative agricultural cooperatives). He took charge of employees' housing problems, designing and building new residential areas near Ivrea such as Borgo Olivetti, Canton Vesco, la Sacca, and Bellavista. These neighborhoods were endowed with main infrastructures like roads and a supply network, to connect them with Ivrea. Furthermore, Olivetti organized a service of low cost transport system to avoid unsustainable urban development. For the same reason Adriano Olivetti encouraged the new recruits' farming activities by giving employees a paid leave on Saturdays.

Olivetti's initiatives for the local area's community were many and diverse, going beyond the factory's surroundings. He financed the Ivrea Civil Hospital and helped open several free clinics for obstetric care and antenatal prophylaxis in the Canavese area. Olivetti's idea that the firm was to be tightly linked with the local area was also evident in the plants' design and architecture chosen for the group's factories. These were built respecting the morphological characteristics of the land and therefore blended in seamlessly with the neighborhood, as shown by the Olivetti plant in Pozzuoli. It was designed to follow the contours of the land and the coastline of the Gulf in front of it. He had a harmonious vision of the relationship between nature and technology, believing that production and culture were two sides of the same coin. In order to enhance the cultural value of his factories Olivetti entrusted many famous architects to design them and filled them with works of art.

Olivetti organized several cultural and artistic events for he wanted "to share culture, aesthetics, and harmony of shapes in the plant's surrounding," 
sinergie Vol. 33, N. 96, 2015

(Gallino, 2001, p. 8). He saw culture as a way to promote the development and empowerment of people so, between 1950 and 1964, the Cultural Center Olivetti was used to host 249 conferences, 71 concerts, 103 art exhibitions, and 52 other events such as political and social debates, and literary presentations, featuring prominent personalities such as Salvemini, Moravia, De Filippo and many others.

Publishing was another way he had developed to fulfill his own philanthropic responsibility. He published Italian editions of seminal works in many fields such as architecture and urban planning, social sciences, economics, sociology, and political science. Moreover he took an active role in founding various scientific journals on several topics such as technology, management and organizational sciences, and the arts. The concept that the various actors present in a given local area should be tightly connected was so central in Adriano Olivetti's vision that it became the cornerstone of its political party: "Movimento di Comunita" (Olivetti, 2013b; 2014).

\subsection{Shareholders}

Olivetti was a classic example of a family business. The Board of Directors was chosen by the family and its members were often selected within the family. Some shareholders accused him to spend too much in social services for the employees. They took advantage of the failure of the Movimento di Comunità political party to ask for his resignation as CEO.

Adriano Olivetti was firmly convinced that the key to sustaining competitive advantage was product innovation both in terms of technology and design. Being successful in the market created a virtuous circle based upon his products' excellence. In this circle the higher profits Olivetti obtained from selling technologically advanced products were invested to find further innovation and growth.

This business model was sound, as shown by the capital turnover of the 1946 - 1958 period which grew 6 times in Italy and 18 times abroad. Even if the dividends were modest and in line with the interest paid on the employees' deposits that were held by the company during his administration (Maggia, 2001) shareholders were able to achieve a clear advantage from their equity share, as the share value grew 22 -fold, in real terms, in the years from 1924 to 1960.

\subsection{Other stakeholders}

The other stakeholders we address are the Italian Union and the Italian entrepreneurial community.

Adriano Olivetti had a mixed-feeling relationship with the unions as well. His way of managing relationships with workers somehow diminished unions' role and decreased their legitimacy as it often anticipated their ideas (Arrigo, 2006). Later on, he encouraged employees to create an association (called Comunità di Fabbrica) to engage the stakeholders in the factory's organization. Even if Comunità di Fabbrica was not a union, it was criticized by CGIL and UIL. Nevertheless, the 
relations between Comunità di Fabbrica and the other unions were friendly. Comunità di Fabbrica was, in his vision, "a first step towards granting greater power to the company's employees" (Gallino, 2001 p. 80).

The relationship between Olivetti and Confindustria, the most important association of manufacturers and service providers in Italy, was however a conflictual one. The more prominent members of Confindustria saw Olivetti as a threat to "orthodox" business principles, as he allowed employees better conditions than other Italian entrepreneurs. As a consequence, Confindustria asked its members to boycott Olivetti's products. Another difference between Adriano Olivetti and the other Italian entrepreneurs, often more oriented towards an Italian perspective than an international one, consists in the different role they attributed to electronics and computing. When he died, the electronic division was a strong competitor to IBM but the steering committee that was created to overcome the Olivetti crisis, decided to sell it to General Electric about 4 years later. The steering committee was composed by the managers of the most important Italian companies like Fiat, Pirelli, Mediobanca, and IMI.

\section{Discussion of findings and further research opportunities}

Adriano Olivetti managed various relationships with the stakeholders, engaging them in a value creation process that was able to increase performance in both the social and the economic dimensions. Furthermore, this case highlights how managing a firm with a stakeholder focus could be a condition for sustainable excellence. In table 1 we summarize findings related to the different levels of responsibility that the various Olivetti's policies have, according to the Pyramid of Corporate Social Responsibility (Carroll, 1979).

Tab. 1: Olivetti's policies in the Corporate Social Responsibility's pyramid

\begin{tabular}{|c|c|}
\hline Responsibility & Policies \\
\hline Economic & $\begin{array}{c}\text { Product and Process Innovation - Organizational Innovation - Human } \\
\text { Resource Management - Reinvestment of Profits - Growth Orientation }\end{array}$ \\
\hline Ethical & $\begin{array}{r}\text { High consideration of labour - Human Resource Management - } \\
\text { Investments in rural areas - Social Services - Factory architecture }\end{array}$ \\
\hline Philanthropic & Cultural activities - Research funding (e.g. sociological studies) \\
\hline
\end{tabular}

Source: our elaboration

If we consider the activities that were carried out by Olivetti's managers when Adriano Olivetti was at the helm, in looking at the results the group reached in international markets we find that this company was a clear example of doing well by doing good (Key and Popkin, 1998). During his administration the Olivetti Group was managed as a stakeholder oriented company. We may find clear evidence of this in his own words: "To say it all, the real common benefit in the factory is a complex function of: the individual 
Sinergie Vol. 33, N. 96, 2015

and direct interests of those working in the enterprise, their supportive and social spiritual interests; the common interests of the community around the firm that are defined and its raison detre; the interests of the territory near the firm" (Olivetti, 2014, p. 50).

As proposed by stakeholder management theory, Adriano Olivetti did not manage the relationships with all stakeholder groups in the same way. The most important stakeholders were clearly the employees - as a source of competences and creativity - that were the innovation cornerstone in Olivetti. Moreover, Adriano Olivetti was able to drive employees to cooperate, not on the basis of their position on the job, but rather by looking only at the employee's capabilities and competences. According to Conti (2006) managers were asked to involve their own employees in their decision-making processes and to evaluate them for their capability to cooperate. This prominence was reflected in a deep engagement strategy. Employees were asked to take an active role in managing the company and they were richly rewarded in terms of salary, career opportunities, and social services. This relationship was managed with a proactive approach (Carroll, 1979) in order to anticipate the potential needs of employees and provide them with services that answered their still unfelt needs before they become manifested. We can clearly classify employees as a friendly stakeholder (Savage et al., 1991). Adriano Olivetti saw a solid relationship with employees as the first step in creating a stable network of win-win relationships with all other stakeholders, especially those of the local area community. Even the community could be reckoned a friendly stakeholder and Olivetti gave back to the communities by supporting town urbanization and developing social services that all citizens could access. His position towards the community was clearly a proactive one, as he started to care for infrastructures and residential areas way before they became needs. On the other hand, he used a different stakeholder strategy with other groups. For example other Italian entrepreneurs, and their main association Confindustria, were seen as non-supportive stakeholders as they did not share the same vision of the enterprise as a social actor having not only the economic responsibility to increase profit, but more broadly that of increasing the general level of well-being in the community. Adriano Olivetti was considered a dangerous example and he was boycotted in order to avoid his perspective on the nature of the firm as a community becoming an example for other entrepreneurs. Relationships with unions and shareholders could be considered monitoring strategies but the position was an accomodative one. Moreover some of Olivetti's policies, were designed to answer the needs of several stakeholder groups. For example, by giving financial support to employees so they could buy their homes in new residential areas with good infrastructure helped employees but it was a useful practice for the local community as well. It helped them avoid urban sprawl, plan urbanization and increase social services for all citizens. The Olivetti Group was innovation-driven and it used innovations to meet its own responsibilities towards several stakeholder groups. On the one hand it adopted, and further developed, an innovative work organization as a way to improve employees' conditions, making their work less repetitive and 
more interesting; on the other hand, the focus on innovation helped Olivetti market advanced products keeping a sustained stream of new successful products. Innovation was instrumental in attaining the ethical responsibility Mauro Sciarelli
Mario Tani Sustainability and stakeholder approach in Olivetti from 1943 that Adriano Olivetti felt towards his employees and, at the same time it the past was used to create a sustainable competitive advantage to create, and share, value.

In table 2 we outline the different stakeholder strategies that Adriano Olivetti used to manage each stakeholder group. In the table we point out the managerial position for each issue that Adriano Olivetti addressed in the company's policies in the RDAP scale by Clarkson (1995) and the general stakeholder relationship management strategy according to the model by Savage et al. (1991).

The case study shows how Adriano Olivetti, in the 50s, was able to create both economic and social value demonstrating that social and financial performances are not diametrically opposed. Moreover, Adriano Olivetti was able to engage stakeholders and manage the related relationships in a way that is really similar to the principles that became widespread as stakeholder engagement in the 80 s.

Tab. 2: Olivetti's position and stakeholder strategy

\begin{tabular}{|c|c|c|c|}
\hline Stakeholder & Issues & Position* & Stakeholder Strategy \\
\hline \multirow{3}{*}{ Employees } & HRM & $\mathrm{P}$ & \multirow{3}{*}{ Stakeholder Involvement } \\
\hline & Welfare System & $\mathrm{P}$ & \\
\hline & Cultural Services & $\mathrm{P}$ & \\
\hline \multirow{5}{*}{ Community } & Cultural Activities & $\mathrm{P}$ & \multirow{5}{*}{ Stakeholder Involvemen } \\
\hline & Housing & $\mathrm{P}$ & \\
\hline & Hospital & $\mathrm{P}$ & \\
\hline & Research Funding & $\mathrm{P}^{* *}$ & \\
\hline & Publishing & $\mathrm{P}^{* *}$ & \\
\hline \multirow{3}{*}{ Shareholders } & Low Dividend Policy & $\mathrm{D}$ & \multirow{3}{*}{ Stakeholder Monitoring } \\
\hline & Social Services' Costs & $\mathrm{D}$ & \\
\hline & Reinvestment of Profits & A & \\
\hline Unions & $\begin{array}{l}\text { Comunità di Fabbrica } \\
\text { (Alternative Internal } \\
\text { Employees Association) }\end{array}$ & A & Stakeholder Monitoring \\
\hline $\begin{array}{c}\text { Italian } \\
\text { Entrepreneurs } \\
\text { Association }\end{array}$ & $\begin{array}{l}\text { Different vision of corporate } \\
\text { responsibility }\end{array}$ & $\mathrm{D}$ & Defensive Strategy \\
\hline
\end{tabular}

*: This column gives the evaluation of the position on the RDAP scale (Clarkson, 1995)

**: This policy has been considered proactive for the general Italian community.

Source: our elaboration 


\section{sinergie} Vol. 33, N. 96, 2015

\section{References}

ACKERMANN F., EDEN C. (2011), "Strategic Management of Stakeholders: Theory and Practice", Long Range Planning, vol. 44, pp. 179-196.

ARRIGO E. (2003), "Corporate Responsibility in Scarcity Economy. The Olivetti Case”, SYMPHONYA Emerging Issues in Management, n. 1, pp. 114-134.

BOWEN H. (1953), Social Responsibilities of the Businessman, Harper \& Row, New York.

CARROLL A.B. (1979), “A three-dimensional conceptual model of corporate performance", Academy of management review, vol. 4, n. 4, pp. 497-505.

CARROLL A.B., BUCHHOLTZ A.K. (2000), Business and Society: Ethics and Stake- holder Management (5th ed.), Thomson-South-Western, Cincinnati.

CHIRIELEISON C. (2002), Strategie sociali nel governo dell'impresa, Giuffrè, Milano.

CLARKSON M.E. (1995), "A stakeholder framework for analyzing and evaluating corporate social performance", Academy of Management Review, vol. 20, n. 1 , pp. 92-117.

CONTI T. (2006), “Lesperienza di Adriano Olivetti”, Sinergie, n. 70, pp. 37-43.

CYERT R.M., MARCH J.G. (1963), A behavioral theory of the firm, Englewood Cliffs, New Jersey.

DAVIS K. (1960), "Can Business Afford to Ignore Social Responsibilities?", California Management Review, vol. 2, n. 3, pp. 70-76.

DAVIS K. (1973), "The case for and against business assumption of social responsibilities", Academy of Management Journal, vol. 16, n. 2, pp. 312322.

DONALDSON T., DUNFEE T.W. (1994), "Towards a unified conception of business ethics: an Integrative Social Contracts Theory", Academy of Management Review, vol. 19, n. 2, pp. 252-284.

DONALDSON T., PRESTON L.E. (1995), "The stakeholder theory of the corporation: Concepts, evidence, and implications", Academy of Management Review, vol. 20, n. 1, pp. 65-91.

DYER J.H., SINGH H. (1998), "The relational view: cooperative strategy and sources of interorganizational competitive advantage", Academy of Management Review, vol. 23, n. 4, pp. 660-679.

EISENHARDT K. (1989), "Agency theory: An assessment and review", Academy of Management Review, vol. 14, n. 1, pp. 57-74.

ELKINGTON J. (1998), Cannibals with forks: The triple bottom line of 21st century business, New Society Publishers, Stony Creek

EVAN W.M., FREEMAN R.E. (1988), "A stakeholder theory of the modern corporation: Kantian capitalism”, in Beauchamp T. L., Bowie N., Ethical theory and business, Prentice-Hall, Englewood Cliffs.

FERRAROTTI F. (2013), La concreta utopia di Adriano Olivetti, Edizioni Dehoniane Bologna, Bologna.

FREDERICK W.C. (1960), “The Growing Concern Over Business Responsibility”, California Management Review, n. 2, pp. 54-61.

FREEMAN R.E. (1984), Strategic management: A stakeholder approach, Pitman Publishing, Boston. 
FREEMAN R.E., HARRISON J.S., WICKS A.C., PARMAR B.L., DE COLLE S. Mauro Sciarelli (2010), Stakeholder theory: The state of the art, Cambridge University Press, Sustainability and Cambridge.

FRIEDMAN M. (1970), “The Social Responsibility of Business Is to Increase Its to 1960: a lesson from stakeholder approach in Olivetti from 1943 Profits", New York Times Magazine, September 13.

FRIEDMAN M. (1962), Capitalism and Freedom, University of Chicago Press, Chicago.

FROOMAN J. (1999), “Stakeholder Influence Strategies", Academy of Management Review, vol. 24, n. 2, pp. 191-205.

GALLINO L., (2001), L'impresa responsabile. Un'intervista su Adriano Olivetti, Edizioni Comunità. Roma

GHOSHAL S. (2005), "Bad management theories are destroying good management practices", Academy of Management Learning and Education, vol. 4, n. 1, pp. 75-91.

GOODPASTER K.E. (1991), "Business ethics and stakeholder analysis", Business Ethics Quarterly, vol. 1, n. 1, pp. 53-73.

HINNA L. (2002), Il bilancio sociale, Il Sole24Ore, Milano.

JONES T.M. (1995), "Instrumental stakeholder theory: a synthesis of ethics and economics", in Academy of Management Review, vol. 20, n. 2, pp. 404-437.

KEY S., POPKIN S.J. (1998), "Integrating Ethics into the Strategic Management Process: Doing Well by Doing Good", Management Decision, vol. 36, n. 5-6, pp. 331-339.

MAGGIA G. (2001), "Soprattutto un grande imprenditore", www.arcoliv.org.

MCGUIRE J.W. (1963), Business and Society, McGraw-Hill, New York.

MCWILLIAMS A., SIEGEL D. (2000), "Corporate social responsibility and financial performance: correlation or misspecification?", Strategic Management Journal, vol. 21, n. 5, pp. 603-609.

MITCHELL R.K., AGLE B.R., WOOD D.J. (1997), “Toward a theory of stakeholder identification and salience: Defining the principle of who and what really counts", Academy of Management Review, vol. 22, n. 4, pp. 853-886.

OCHETTO B. (2013), Adriano Olivetti. La biografia, Edizioni di Comunità, Roma.

OLIVETTI A. (2012), Ai Lavoratori, Edizioni di Comunità, Roma.

OLIVETTI A. (2013a), Il mondo che nasce, Edizioni di Comunità, Roma.

OLIVETTI A. (2013b), Il Cammino della Comunità, Edizioni di Comunità, Roma.

OLIVETTI A. (2014), Le fabbriche di bene, Edizioni di Comunità, Roma.

ORLITZKY M., SCHMIDT F.L., RYNES S.L. (2003), "Corporate social and financial performance: A meta-analysis”, Organization Studies, vol. 24, n. 3, pp. 403 441.

PATTEN D.M. (1992), "Exposure, legitimacy, and social disclosure”, Journal of Accounting and Public Policy, vol. 10, n. 4, pp. 297-308.

PFEFFER J., SALANCIK G.R. (1978), The external control of organizations, Harper \& Row., New York.

PIOL E. (2004), Il Sogno di un’impresa, Il Sole 24 Ore Libri, Milano.

PRESTON L.E., POST J.E. (1981), “Private management and public policy”, California Management Review, vol. 23, n. 3, pp. 56-62.

ROWLEY T.J. (1997). "Moving beyond dyadic ties: A network theory of stakeholder influences", Academy of Management Review, vol. 22, n. 4, pp. 887-910.

RUSCONI G. (2007), "Stakeholder e documenti di accountability diretta delle imprese”, in Freeman R. E., Rusconi G., Dorigatti M., Teoria degli Stakeholder, FrancoAngeli, Milano. 


\section{sinergie} Vol. 33, N. 96, 2015

SAVAGE G.T., NIX T.W., WHITEHEAD C.J., BLAIR J.D. (1991), "Strategies for assessing and managing organizational stakeholders", The Executive, vol. 5, n. 2, pp. 61-75.

SCIARELLI M. (2012), Corporate Social Performance. Il valore allargato nella prospettiva degli stakeholder, Cedam, Padova.

SCIARELLI M., TANI M. (2013), "Network approach and Stakeholder Management", Business Systems Review, vol. 2, n. 2, pp. 175-190.

SCIARELLI S. (1999), "Corporate Ethics and the Entrepreneurial Theory of "Social Success", Business Ethics Quarterly, vol. 9, n. 4, pp. 639-649.

SCIARELLI S. (2007), Etica e Responsabilità Sociale nell'Impresa, Giuffrè Editore, Milano.

SEN A. (1987), On Ethics and Economics, Wiley-Blackwell, Oxford.

SETHI S.P. (1975), "Dimensions of Corporate Social Responsibility", California Management Review, vol. 17, n. 3, pp. 58-64.

SIMON H.A. (1947), Administrative Behavior, Macmillan Press, New York.

SIRGY M. J. (2002), "Measuring corporate performance by building on the stakeholders model of business ethics", Journal of Business Ethics, vol. 35, n. 3, pp. 143-162.

STOUT L.A. (2012), The shareholder value myth: How putting shareholders first harms investors, corporations, and the public, Berrett-Koehler Publishers, San Francisco.

VERBEKE A., TUNG V. (2013), "The future of stakeholder management theory: a temporal perspective", Journal of Business Ethics, vol. 112, n. 3, pp. 529543.

WARTICK S.L., COCHRAN P.L. (1985), “The evolution of the corporate social performance model", Academy of Management Review, vol. 10, n. 4, pp. 758-769.

WOOD D.J. (1991), “Corporate social performance revisited”, Academy of Management Review, vol. 16, n. 4, pp. 691-718.

WOOD D.J. (2010), "Measuring corporate social performance: a review. International", Journal of Management Reviews, vol. 12, n. 1, pp. 50-84.

WRIGHT P., FERRIS S.P. (1997), "Agency conflict and corporate strategy: The effect of divestment on corporate value", Strategic Management Journal, vol. 18, n. 1, pp. 77-83.

\section{Academic or professional position and contacts}

\section{Mauro Sciarelli}

Full professor of Business Management

University of Naples Federico II, Italy

email: mauro.sciarelli@unina.it

sinergie Mario Tani

italian journal of management

ISSN 0393-5108

Research Fellow of Business Management

DOI $10.7433 / \mathrm{s} 96.2015 .02$

University of Naples Federico II, Italy

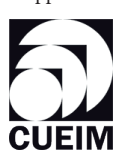

email: mario.tani@unina.it 